\title{
Importance of Cytoplasm in Plant Genetics
}

\author{
Hitoshi Kihara \\ Kihara Institute for Biological Research, Mutsukawa 3-122-21, \\ Minami-ku, Yokohama, 232 Japan
}

Received October 21, 1981

The main purpose of this paper is to combine old findings together with results from the recent studies on cytoplasm and to discuss the importance of cytoplasm for plant breeding and evolution.

Within a species, the study on cytoplasm can be conducted by observing differences of $F_{1}$ hybrids between the reciprocal crosses. However, the establishment of nucleus-cytoplasm substitution lines is needed for the detailed analysis for genetic studies on cytoplasm, especially in interspecific hybrids. In animals, e. g. in frogs, the nucleus-cytoplasm substitution can be accomplished by transplanting a paternal nucleus into the egg cell after the nucleus of an unfertilized egg is removed. In plant, it is achieved through a biological procedure, namely by backcrossing.

Although $I$ have shown in many occasions the procedure for obtaining the nuclear substitution and restoration lines between two parental species in higher plants, I would like to illustrate a schematic diagram in Fig. 1. to show how these lines could be obtained. One example in my experiment of wheat and its relatives is as follows;

Substitution backcrosses

(q)

Ae. caudata

$\mathrm{F}_{1}$

$\mathrm{SB}_{1}$

$\mathrm{SB}_{2}$

$\mathrm{SB}_{\mathrm{n}-1}$ $(\overbrace{}^{-1})$

$\times T$. vulgare

$\times T$. vulgare

$\times T$. vulgare

$\times T$. vulgare

$\times T$. vulgare

(d)

$\times$ Ae, caudata

$\times T$. vulgare

$\times T$. vulgare

$\times T$. vulgare

$\times T$. vulgare

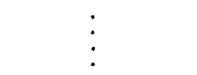

$\mathrm{F}_{1}$

$\mathrm{SB}_{1}$

$\mathrm{SB}_{2}$

$\mathrm{SB}_{3}$

$\mathrm{SB}_{\mathrm{n}}$

Restoration backcrosses

(q)

T. vulgare

$\mathrm{F}_{1}$

$\mathrm{RB}_{1}$

$\mathrm{RB}_{2}$

$\mathrm{RB}_{\mathrm{n}-1}$$$
\times T . \text { wigare }
$$

caudata. and T. vulgare were estimated to complete after $\mathrm{B}_{5}$ generation because the pollen fertility of $\mathrm{SB}_{5}$ plants were $0 \%$, while their seed set with pollen of $T v e$ were normal. As for the restoration, I saw 
that the pollen as well as seed fertilities were both normal at the $\mathbf{R B}_{5}$ generation (Kihara 1959). I use the symbols for these substitution and restoration lines as follows;

$$
\begin{aligned}
& \text { SB : } \\
& \text { RB : caud) Tve }
\end{aligned}
$$

where the names in parenthesis are for the donors of cytoplasm. The restoration line is very important for the control of the experiments. Backcrosses for both lines have been successively continued until $B_{32}$ (1981).

At the beginning when I had started the study on the cytoplasm in 1936, only one backcross generation was proceeded per year. Later, by adopting Mukade's method for acceleration of generation (Mukade et al. 1973), I could get five to six
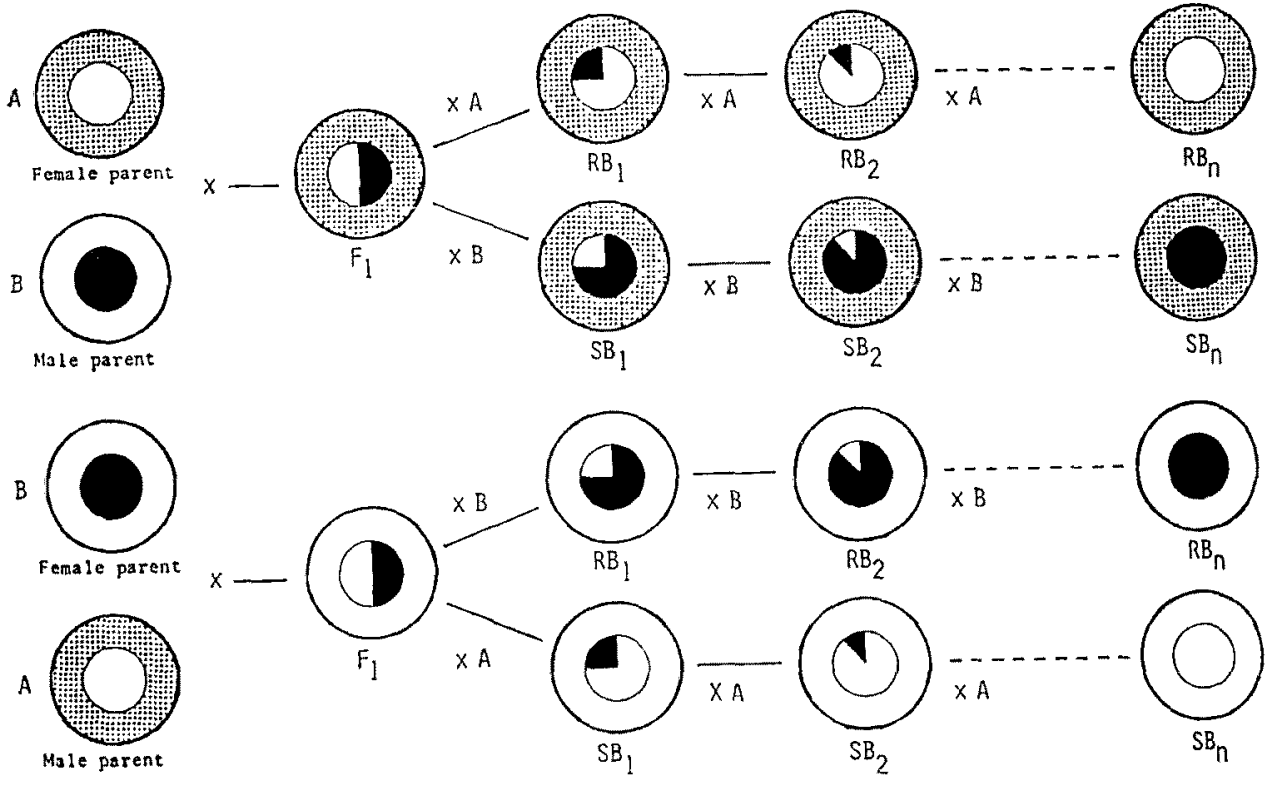

Fig. 1. Diagram showing the restoration and substitution of nucleus between two species by successive back-crosses.

generations per year if the materials are spring type. Therefore, we need only two years to get the new RB and SB lines for investigations of cytoplasm, while the old lines are kept by backcrossing every year. In this way, we have been maintaining about 200 substitution lines having nucleus of common wheats or Emmer wheats the combination of cytoplasms of almost all species of Aegilops.

\section{Characteristics of cytoplasm as a hereditary substance}

Transmission of all hereditary materials of cytoplasm in higher organisms is so far one-sided, namely all descendants from the crosses receive the cytoplasm only from female parent. In some cases, it was reported that cytoplasmic characteristics of male parents are inherited in the offspring. However, it is most probable that the two parents belonging to the same species are isoplasmic (cytoplasmically homo- 
logous). In these cases, a small quantity of paternal cytoplasm could be transmitted to the egg cell without any damage.

Since hereditary substances of cytoplasm are transmitted only through female parent in most cases, cytoplasmic characteristics are inherited conservatively through many generations, which indicates the constancy of cytoplasmic inheritance. I can show two examples of the cytoplasmic constancy from my experiments.

First; a nucleo-cytoplasmic substitution line of (caud)Tve has been maintained for more than 30 years by means of backcrossing. It keeps its characteristic phenotypes of male sterility and weakness of plant vigor due to the interaction between the cytoplasm of Ae. caudata and nuclear genome of $T v e$.

Second; T. compactum 44 (abbrebiation; Comp 44) has a gene of male-fertility restoration for caudata cytoplasm (namely, (caud)Comp 44 is male fertile). When (caud) Comp 44 is successively backcrossed with pollen of $T v e$, the plants obtained become male sterile again.

With the similar way, I could prove that the Ae. ovata cytoplasm from (ovata) CS (male fertile) did not change its character of male sterility with the combination of Tve nucleus. These instances imply that genetic characteristics of cytoplasm remain constant throughout hybridization for many generations.

An old hypothesis claimed that the fundamental differences between species, genera, or the higher taxonomic units were due to differences of plasmon. This hypothesis had initially got strong supports from investigations of interspecific or intergeneric hybrids; the greater was the differences between two parental species, the greater were differences between their reciprocal hybrids. As genetic analysis on nuclear genes had been developed, this old hypothesis had been denied and the role of cytoplasm has been neglected for long time.

In case of intergeneric hybrids of Triticinae, the large morphological differences were not recognized between two lines of the reciprocal crosses (i.e. Ae. caudata $\times$ Tve, and its reciprocal). However, differences have been found in nuclear cytoplasmic hybrid of (caud)Tve in comparison with normal Tve or with the restoration backcrossing line. The differences are due to the genetic characteristics of their cytoplasms.

\section{Nucleo-cytoplasmic heterosis}

When cytoplasmic male sterility and fertility restoring genes were discovered, a big sensation arose as a hybrid wheat breeding might be possible. There are several candidates for cytoplasmic sources which induce complete male sterility without any deteriorating effects on plant growth like the cytoplasm of T. timopheevi or T. zhukovskyi. However, the hybrid wheat breeding program is not yet fully established, mainly because we have not obtained stable fertility restorer. Also, there remains trouble to be solved in cultivation technique to obtain high percentage of hybrid seed production.

Many nucleo-cytoplasmic hybrids (NC-hybrids) have been established by using most of Aegilops species as cytoplasmic sources with combinations of various common wheat strains as nuclear donors. It was found that each cytoplasm had specific effects on genome manifestations of wheat. Table 1. shows some examples 
of the NC-hybrids in hexaploid wheat having cytoplasms of four Aegilops species. From this table, we can see the caudata cytoplasm induces male sterility to all $6 \mathrm{x}$ wheats except $T$. compactum 44 and P168 (a 6x strain derived from $T$ ve $\times$ Ae. caudata)

Table 1. Reaction spectra of nucleus and cytoplasm in the NC-hybrids of Triticum and Aeqilops

\begin{tabular}{|c|c|c|c|c|c|c|c|c|}
\hline \multirow{2}{*}{$\begin{array}{l}\text { Nucleus donor } \\
\text { (flowering date) }\end{array}$} & \multicolumn{8}{|c|}{ Cytoplasm } \\
\hline & \multicolumn{2}{|c|}{ Ae. caudata } & \multicolumn{2}{|r|}{ Ae. ovata } & \multicolumn{2}{|c|}{ Ae. umbellulata } & \multicolumn{2}{|c|}{ Ae. squarrosa } \\
\hline \multirow{3}{*}{$\begin{array}{l}\text { T.v.e } \\
\text { (May 20) }\end{array}$} & $1^{*}$ & st & 1 & st & 1 & p. $\mathrm{ft}$ & & $\mathrm{ft}$ \\
\hline & $2^{*}$ & normal & 2 & normal & 2 & dwarf & 2 & normal \\
\hline & & late $(+2)$ & 3 & late $(+10)$ & 3 & late $(+2)$ & 3 & early $(-2)$ \\
\hline \multirow{3}{*}{$\begin{array}{l}\text { T. compactum } 44 \\
\text { (May 16) }\end{array}$} & 1 & $\mathrm{ft}$ & 1 & st & 1 & p. $\mathrm{ft}$ & 1 & $\mathrm{ft}$ \\
\hline & 2 & normal & 2 & normal & 2 & normal & 2 & normal \\
\hline & & late $(+2)$ & 3 & late $(+11)$ & 3 & late $(+11)$ & 3 & early $(-9)$ \\
\hline \multirow{3}{*}{$\begin{array}{l}\text { Chinese Spring } \\
\text { (May 8) }\end{array}$} & 1 & st & 1 & $\mathrm{ft}$ & 1 & p. $\mathrm{ft}$ & 1 & $\mathrm{ft}$ \\
\hline & & dwarf & 2 & normal & 2 & dwarf & 2 & normal \\
\hline & & late $(+1)$ & 3 & late $(+6)$ & 3 & late $(+6)$ & 3 & early $(-4)$ \\
\hline \multirow{3}{*}{$\begin{array}{l}\text { Norin } 26 \\
\text { (Apr. 29) }\end{array}$} & 1 & st & 1 & st & 1 & p. $\mathrm{ft}$ & 1 & $\mathrm{ft}$ \\
\hline & 2 & normal & 2 & normal & 2 & dwarf & 2 & normal \\
\hline & 3 & late $(+2)$ & 3 & late $(+4)$ & 3 & late $(+5)$ & 3 & late $(+1)$ \\
\hline \multirow{4}{*}{$\begin{array}{l}\text { Jones Fife } \\
\text { (May 19) }\end{array}$} & 1 & st & 1 & st & 1 & p. $\mathrm{ft}$ & 1 & $\mathrm{ft}$ \\
\hline & & normal & 2 & normal & 2 & normal & 2 & normal \\
\hline & & late $(+4)$ & 3 & late $(+11)$ & 3 & late $(+1)$ & 3 & late $(+3)$ \\
\hline & 1 & st & 1 & st & 1 & st & 1 & $\mathrm{ft}$ \\
\hline \multirow{2}{*}{$\begin{array}{l}\text { Salmon } \\
\text { (May 13) }\end{array}$} & 2 & normal & 2 & normal & 2 & dwarf & 2 & normal \\
\hline & & late $(+4)$ & 3 & late $(+15)$ & 3 & late $(+7)$ & & early $(-2)$ \\
\hline \multirow{3}{*}{$\begin{array}{l}\text { Selkirk } \\
\text { (May 13) }\end{array}$} & 1 & st & 1 & st & 1 & p. $\mathrm{ft}$ & 1 & $\mathrm{ft}$ \\
\hline & 2 & normal & 2 & normal & 2 & dwarf & 2 & normal \\
\hline & 3 & late $(+4)$ & 3 & late $(+3)$ & 3 & late $(+9)$ & 3 & early $(-8)$ \\
\hline
\end{tabular}

$1^{*}$ pollen fertility, $2^{*}$ growth, $3^{*}$ flowering date compared with that of nucleus donor. $(-9)$ means 9 days earlier than the control. $s t=$ sterile, $\mathrm{ft}=$ fertile, $\mathrm{p} . \mathrm{ft}=$ partially fertile (results of 1974).

Table 2. General effects of alien cytoplasm to common wheat

\begin{tabular}{|c|c|c|c|c|}
\hline \multirow{2}{*}{ Character } & \multicolumn{4}{|c|}{ Cytoplasmic donors } \\
\hline & caudata & ovata & umbellulata & squarrosa \\
\hline Growth & normal & normal & weak & normal \\
\hline Heading date & normal & very late & late & normal \\
\hline Pollen fert. & sterile & sterile & semi-sterile & fertile \\
\hline $\begin{array}{l}6 x \text { wheat having } \\
\text { Fertility restorer }\end{array}$ & P168 Comp 44 & $\mathrm{CS}$ & - & all $6 \mathrm{x}$ wheats \\
\hline Other characteristics & $\begin{array}{l}\text { Haploid } \\
\text { induction }\end{array}$ & $\begin{array}{l}\text { Alteration } \\
\text { of growth } \\
\text { habit }\end{array}$ & $\begin{array}{l}\text { Chlorophyll } \\
\text { deficiency }\end{array}$ & $\begin{array}{l}\text { Possibility } \\
\text { for NC- } \\
\text { heterosis }\end{array}$ \\
\hline
\end{tabular}

which have the male fertility restoring genes. The ovata cytoplasm is characteristic in inducing delay of maturation beside male sterility, while the umbellulata cytoplasm has the tendancy to make the NC-hybrids a little shorter in height and late maturity 
with semi-sterility of pollen. The squarrosa cytoplasm is very different from the other, namely the NC-hybrids of $6 \mathrm{x}$ wheat having squarrosa cytoplasm are all normal in plant growth and fertility. These relationships are summerized in Table 2.

The squarrosa cytoplasm is conspicuous from the aspect of plant breeding because all NC-hybrid wheat lines with squarrosa cytoplasm showed normal fertility and vigor. With some nuclei, these lines headed and matured earlier than the controls, which suggested the possibility to utilize the NC-hybrid lines with squarrosa cytoplasm for wheat breeding.

It was proved that the cytoplasm of squarrosa is genetically different from those of tetraploid and hexaploid wheats: The cytoplasms of tetraploid and hexaploid wheats were determined to have been inherited from an unknown diploid species

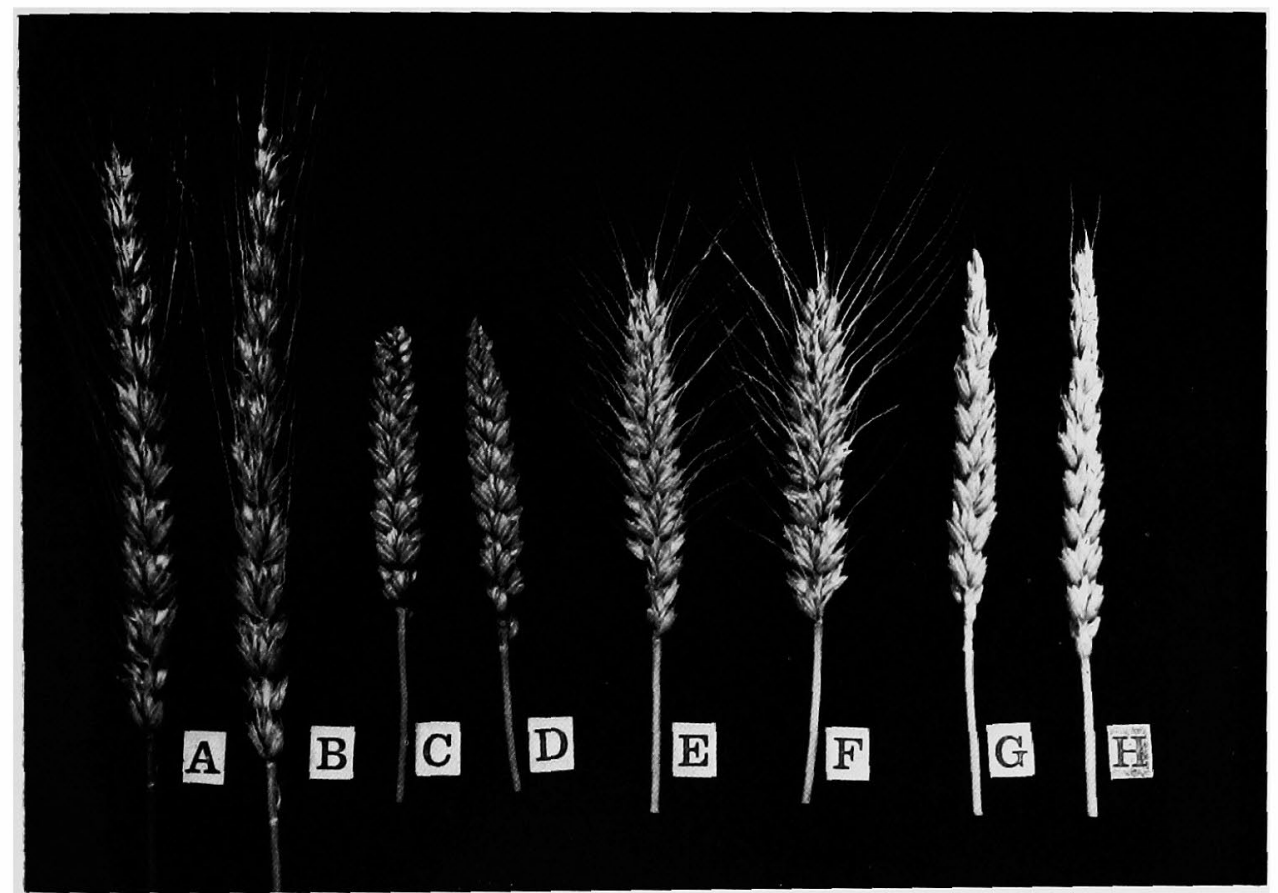

Fig. 2. Ears of four NC-hybrids and their nucleus donors. A: T.v.e.. B: (squarrosa)-T.v.e.. C: Chinese Spring. D: (squarrosa)-Chinese Spring. E: Norin 26. F: (squarrosa)-Norin 26. G: Selkirk. H: (squarrosa)-Selkirk.

having B genome (Kihara 1973, Tsunewaki 1980). Therefore, (squa)Dinkels are alloplasmic, and one of the $\mathrm{D}$ genome chromosomes (which was identified as $1_{\mathrm{D}}$ in common wheats) has the fertility restoration gene for squarrosa cytoplasm. These facts suggest that common wheat lines with squarrosa cytoplasm might be useful for wheat improvement by means of broadening cytoplasmic background, expecting heterotic effects by alien cytoplasm. I had proposed this type of breeding as nucleocytoplasmic heterosis (NC-heterosis) breeding (1975). Fig. 2 shows spikes of NChybrids together with their nucleus donors. Results from the yield trial at two locations (Hokkaido, Japan and Washington, USA) with these NC-hybrids are shown in Table 3 and Table 4, respectively. These data indicate that squarrosa cytoplasm 
does not have deteriorating effect on common wheat. There was no negative effects on seed quality or disease resistance in these NC-hybrid lines (Kihara 1979). Further experiments are being conducted for agronomic studies by using other nu-

Table 3. Characteristics of NC-hybrids (spring type) having squarrosa cytoplasm at Hokkaido, Japan (1980)

\begin{tabular}{lcccccccccc}
\hline \multicolumn{1}{c}{ Line } & $\begin{array}{c}\text { Stem } \\
\text { length } \\
\text { (cm) }\end{array}$ & $\begin{array}{c}\text { Heading } \\
\text { date }\end{array}$ & $\begin{array}{c}\text { Flower- } \\
\text { ing } \\
\text { date }\end{array}$ & $\begin{array}{c}\text { Height } \\
\text { (cm) }\end{array}$ & $\begin{array}{c}\text { Spike } \\
\text { length } \\
\text { (cm) }\end{array}$ & $\begin{array}{c}\text { No. of } \\
\text { spike }\end{array}$ & $\begin{array}{c}\text { No. of } \\
\text { fertile } \\
\text { tiller }\end{array}$ & $\begin{array}{c}\text { Seed } \\
\text { weight } \\
\text { (g) }\end{array}$ & $\begin{array}{c}100 \text { seed } \\
\text { weight } \\
\text { (g) }\end{array}$ \\
\hline Tve & 63 & 77.7 & 79.4 & 108 & 15.8 & 33.0 & 31.1 & 32.6 & 4.0 \\
(sq) Tve & $71^{* *}$ & $74.4^{* *}$ & $75.7^{* *}$ & 110 & 15.7 & 40.0 & 38.1 & 40.3 & $3.8^{* *}$ \\
P168 & 58 & 77.8 & 79.4 & 109 & 15.5 & 31.3 & 28.4 & 22.5 & 3.2 \\
(sq) P168 & $68^{* *}$ & 75.6 & $77.1^{*}$ & $113^{* *}$ & 15.9 & $38.5^{*}$ & $35.3^{*}$ & $31.7^{* *}$ & 3.3 \\
CS & 64 & 70.3 & 71.4 & 85 & 8.3 & 20.5 & 18.4 & 15.7 & 2.5 \\
(sq) CS & 69 & 70.0 & 71.1 & $87^{*}$ & $8.8^{*}$ & $25.4^{* *}$ & $22.9^{* *}$ & $19.3^{*}$ & 2.6 \\
N26 & 63 & 61.6 & 64.2 & 55 & 6.7 & 25.1 & 23.0 & 15.4 & 2.4 \\
(sq) N26 & 60 & $63.5^{*}$ & $66.1^{*}$ & 55 & $7.3^{*}$ & 26.3 & 24.8 & 16.1 & $2.3^{*}$ \\
Selk & 67 & 67.0 & 69.0 & 87 & 10.2 & 41.0 & 34.1 & 20.4 & 3.1 \\
(sq) Selk & 68 & 66.5 & 68.8 & $90^{*}$ & 10.4 & 39.8 & 35.8 & 19.3 & 3.3 \\
C44 & 49 & 78.8 & 80.1 & 101 & 5.5 & 38.4 & 33.4 & 25.5 & 3.0 \\
(sq)C44 & 52 & 77.6 & 79.0 & 101 & 5.4 & 37.3 & 32.1 & 22.6 & 3.0 \\
Spd & 48 & 83.5 & 84.5 & 111 & 12.5 & 41.5 & 38.0 & 23.0 & 3.4 \\
(sq) Spd & 48 & 81.6 & 82.7 & $107^{*}$ & 12.2 & 40.9 & 34.7 & 20.9 & 3.5 \\
SpR & 55 & 80.4 & 81.8 & 99 & 16.4 & 24.6 & 22.7 & 21.0 & 3.4 \\
(sq) SpR & $63^{* *}$ & $78.2^{*}$ & $79.4^{*}$ & 99 & 16.8 & 29.0 & 25.3 & 24.1 & 3.6 \\
\hline
\end{tabular}

Recorded in June $24,1980$.

$*$ *** significant as $1 \%$ and $5 \%$ level against normal line.

Table 4. Agronomic performance of NC-hybrids (winter type) having squarrosa cytoplasm at two locations in Washington State, USA (1981)

(cooperated with Drs C. F. Konzak and R. E. Allan, Washington St. Univ.)

\begin{tabular}{|c|c|c|c|c|c|}
\hline Location & Line & $\begin{array}{l}\text { Plant height } \\
(\mathrm{cm})\end{array}$ & $\begin{array}{l}\text { No. of tiller } \\
\left(\text { per } \mathrm{m}^{2}\right)\end{array}$ & $\begin{array}{l}\text { Seed weight } \\
(\mathrm{kg} / 10 \mathrm{a})\end{array}$ & $\begin{array}{c}\text { 1000-kernel wt } \\
(\mathrm{g})\end{array}$ \\
\hline \multirow[t]{6}{*}{ Walla Walla } & Gaines & - & 483 & 255 & 22.8 \\
\hline & (sq) Gaines & - & 454 & 325 & 24.2 \\
\hline & Nugaines & - & 470 & 329 & 22.6 \\
\hline & (sq) Nugaines & - & 479 & 388 & 22.3 \\
\hline & Bison & - & - & 334 & 32.9 \\
\hline & (sq) Bison & - & $\ldots$ & 312 & 31,1 \\
\hline \multirow[t]{6}{*}{ Pullman } & Gaines & 107 & 758 & 583 & 16.6 \\
\hline & (sq) Gaines & 117 & 898 & 617 & 20.5 \\
\hline & Nugaines & 111 & 748 & 584 & 19.4 \\
\hline & (sq) Nugaines & 105 & 908 & 638 & 19.0 \\
\hline & Bison & 124 & 902 & 252 & 28.9 \\
\hline & $(s q)$ Bison & 130 & 874 & 329 & 28.6 \\
\hline
\end{tabular}

clear donors of conventional varieties. Also, various strains of squarrosa including var. typica, strangulata, meyeri, and anathera are being introduced into common wheats as cytoplasmic donors in order to obtain the cytoplasmic variation within a species. Existence of cytoplasmic diversity within a species is very probable be- 
cause I have already reported it in caudata (Kihara and Ohta 1971), and there is a wide morphological variation in squarrosa collected from eastern Asia (Kihara et al. 1958).

The ovata cytoplasm has characteristic effects on genome manifestations of wheat. In the experiments with Chinese Spring, a variety of spring wheat having fertility restoration genes for ovata cytoplasm, it was proved that this cytoplasm not only delayed maturity, but also altered plant growth habit from spring type to winter type. The (ovata) CS sown in fall matured late by 10-15 days after spring-sown normal CS, while it remained rosette and sometime headed 30-40 days after the normal when sown in spring.

When (ovata) CS was sown in fall like other winter wheats in Hokkaido, where winter is very severe sometime with the temperature of $-30^{\circ} \mathrm{C}$, (ovata) CS behaved like a winter wheat in contrast to the normal CS which was killed severely. Such changes are hardly possible by gene mutations. Some characteristics with (ovata) CS were summarized in Table 5, while detailed descriptions were published elswhere (Kinoshita, Ohtsuka and Kihara 1980).

Table 5. Characteristics of (ovata) Chinese Spring from the experiments at Hokkaido. $(1981)^{1}$

\begin{tabular}{|c|c|c|c|c|c|}
\hline & $\begin{array}{c}\text { Winter } \\
\text { survival } \\
(\%)\end{array}$ & $\begin{array}{l}\text { Heading } \\
\text { date }\end{array}$ & $\begin{array}{c}\text { Seed wt } \\
(\mathrm{kg} / \mathrm{a})\end{array}$ & $\begin{array}{c}\text { 1000-kernel } \\
\text { wt }(g)\end{array}$ & $\begin{array}{l}\text { Protein } \\
\text { content } \\
\text { (mg/g) }\end{array}$ \\
\hline \multicolumn{6}{|l|}{ Fall sowing } \\
\hline $\mathrm{CS}$ & 16.4 & June 23 & 20.5 & 28.6 & 16.01 \\
\hline (ov) $\mathrm{CS}$ & 72.1 & July 2 & 8.8 & 30.5 & 20.14 \\
\hline \multicolumn{6}{|l|}{ Spring sowing } \\
\hline $\mathrm{CS}$ & - & July 14 & 24.3 & 23.1 & 20.01 \\
\hline (ov) $\mathrm{CS}$ & - & Aug $16^{*}$ & 0.0 & - & - \\
\hline
\end{tabular}

* Plants remained rosette with rare heading.

1) Cooperated with Dr. S. Sawada, Obihiro Univ.

The NC-hybrid breeding technique is also important from the aspect of avoiding genetic vulnerability of cytoplasm. The lesson from the case of Texas cytoplasm in corn reminds us the necessity to broaden the cytoplasmic back-ground in cultivated plants.

\section{Problems related to cell fusion}

There are many examples of so-called hybrid cells which are the products of in vitro fusion of two different somatic cells. One of wellknown examples is a hybrid cell from man and mouse. After repeated cell divisions, the genome of man is eliminated. So far as I am aware, in all hybrid cells in animals, one of the genomes contributed to the hybrid cells is eliminated as shown in Table 6 . As for the fate of the cytoplasm, we do not know yet.

In plants, pomato, an imaginal hybrid presumably obtained between potato and tomato, is widely known. Since it is very attractive to the public, this case is often illustrated in some popular magazines. It is not probable that such a plant called pomato produces normal tomato fruits on the branches above the earth and potatoes 
underground. Recent investgations by Melchers et al. (1978) indicate that four somatic hybrids were obtained from the cell fusion in vitro of two different protoplasts, one from potato and the other from tomato. From their description, the nucleus seems to have approximately 50 chromosomes which corresponds nearly to the sum of the parental chromosome numbers $(24+24)$. As for the cytoplasm of these somatic hybrids, it seems that all four strains have the cytoplasms of the both parents.

As we see in Table 10 of chapter VI, all polyploid Aegilops species of Vertebrata have been proved to inherit their cytoplasm from their maternal parents in natural evolution; there is no mixture of parental cytoplasms in nature. This might be the reason why Melchers et al. (1978) could not obtain amphidiploids which should be normal in fertility and growth.

Table 6. Examples of hybrid cells in animals during culturing in vitro

\begin{tabular}{lll}
\hline \multicolumn{2}{c}{ Combination } & Nucleus eliminated \\
mouse & man & man \\
man & chinese hamster & man \\
man & mosquito & mosquito \\
mouse & monkey & monkey \\
mouse & mule & mule \\
mouse & chicken & chicken \\
\hline
\end{tabular}

(After Yuasa 1980)

Table 7. Types and frequencies of progeny obtained from interspecific crosses between Hordeum vulgare (VV) and H. bulbosum (BB)

\begin{tabular}{|c|c|c|c|c|c|c|c|}
\hline \multicolumn{3}{|c|}{ Combination } & \multicolumn{4}{|c|}{ Genome type and Chromosome number } & \multirow{2}{*}{ Total } \\
\hline q & & 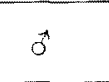 & $\begin{array}{c}\mathrm{V} \\
(7)\end{array}$ & $\begin{array}{l}\text { VV } \\
(14)\end{array}$ & $\begin{array}{l}\text { VB } \\
(14)\end{array}$ & $\begin{array}{l}\text { VBB } \\
\text { (21) }\end{array}$ & \\
\hline VV & $x$ & BB & 1519 & 0 & 26 & 1 & 1566 \\
\hline $\mathrm{BB}$ & $x$ & $\mathrm{VV}$ & 35 & 0 & 0 & 0 & 35 \\
\hline VV & $x$ & BBBB & 0 & 0 & 87 & 0 & 87 \\
\hline BBBB & $x$ & VV & 0 & 0 & 6 & 0 & 6 \\
\hline
\end{tabular}

(Kasha 1974)

To compare the results of hybrid cells with those of interspecific hybrids, I can give an interesting example using two barley species, Hordeum vulgare and $H$. bulbosum. Table 7 is the results reported by Kasha (1974). He obtained many haploid plants by the interspecific crosses of these species.

In general, haploids can be obtained through two ways: 1) The haploid embryo is formed by parthenogenesis in the embryo sac before the sperm reaches to the embryo sac. The fertilization takes place only with pole nuclei forming the endosperm which is useful for the germination of seeds. It was found that the haploid embryos without endosperm do not survive. This process was found in Einkorn wheat (Triticum monococcum), with which many haploid individuals $(30 \%)$ were obtained by delayed pollination (Kihara and Katayama 1942). Haploid formation in the crosses between two distinct species might be quite similar to this example. 
However, this may not be applied to the haploid formation in barley. 2) The normal fusion of male and female nuclei takes place and the paternal or maternal nucleus is eliminated after cell divisions. The phenomenon of genome elimination was observed in the hybrid cells in animals.

The second process of haploid formation fits well with the findings in Hordeum hybrid. Kasha found that the whole bulbosum genome had been eliminated after fertilization, resulting in haploid formation of vulgare in the interspecific hybridization. The bulbosum genome, B, might have been eliminated due to the alloplasmic environment of vulgare cytoplasm, namely (vulgare) $\mathrm{VB} \rightarrow($ vulgare $) \mathrm{V}$. However, in the reciprocal cross between bulbosum ( $q$ ) and vulgare $(\delta)$. Kasha found that bulbosum genome was eliminated in bulbosum cytoplasm, which was also ascertained in the embryological observation. Therefore, some interaction or competition might be present between vulgare and bulbosum genomes which led to the elimination of the latter. So far as the cytoplasmic effects in this system, he reported that diploid plants obtained by chromosome doubling from (vulgare) $\mathrm{V}$ grew normally, while the diploids from (bulbosum) $\mathrm{V}$ were weak and semisterile in pollen fertility. Haploid formation due to chromosome (genome) elimination is a quite new and important study. We should study about the relationships between cytoplasm and nucleus during mitosis. Also, relationship between different nuclei must be studied.

Recently, Hirai (1981) reported an interesting research about the fate of cytoplasm in the cell hybrid in Nicotiana. Isozyme pattern of fraction I protein (FI) in chroloplasts is different between $N$. glauca and $N$. langsdorffi. One of subunits of FI is known to be coded by chroloplast DNA. When protoplasts from both lines were treated with polyethylen-glycole, hybrid cells were obtained, which could grow on a selective medium to form callus. It was found that the callus differentiated to have cytoplasm of either glauca or langsdorffi when they were left to grow during subculture, even though they maintained the whole chromosome sets of both species. Plants restored from the hybrid callus showed identical to the amphidiploid between the two species, but their cytoplasm were identified to be either of glauca or langsdorffi, but not of the mixture type. These facts indicate that there must be cytoplasmic competition and selection for cell to reach physiological stability or affinity between nuclear genome and cytoplasm.

\section{Cytoplasm as a cause of hybrid sterility}

Since my studies on the pentaploid hybrids between Emmer and Dinkel wheats, the fertility of male and female gametes were the measure for the relationship of the parents. The cytoplasms of their parents are identical originated from a common ancestor of BB-genome species. Therefore, the fertility of the hybrids is rather high, and among the offsprings obtained by selfing, I could obtain two constant types, one having $2 n=28$ and the other $2 n=42$. These two types have normal seed as well as pollen fertility like their parents. The sterility found in the $F_{1}$ hybrids or their offsprings is caused by defficiency of the genome.

Another example of sterility is the hybrids between Ae. caudata and $T$. vulgare erythrospermum (Tve), where their cytoplasms are different each other. Therefore, the reciprocal hybrids possess different combinations, namely (caudata) ABCD and 
(aestivum)ABCD. The first hybrid is used for substitution line. The end-product is (caudata)AABBDD which is male sterile, while the female is functional. The reciprocal hybrid, (aestivum) $\mathrm{ABCD}$ is the type which belongs to the first category described below. In this case, with the progress of restoration backcross, the offsprings became totally normal, namely $T$ ve.

Two types of hybrid sterility could be categorized as follows:

1. Genomic sterility; sterility is caused by incompleteness of genomes.

2. Cytoplasmic sterility; sterility is caused by a forein cytoplasm.

When I was observing the pollen grains of sterile hybrids, I have found that the pollen grains of genomic sterile hybrids produced pollen grains of Type $\mathrm{I}$ to $\mathrm{V}$ with the skew frequency distribution given in Fig. 3a, while that from the second type of

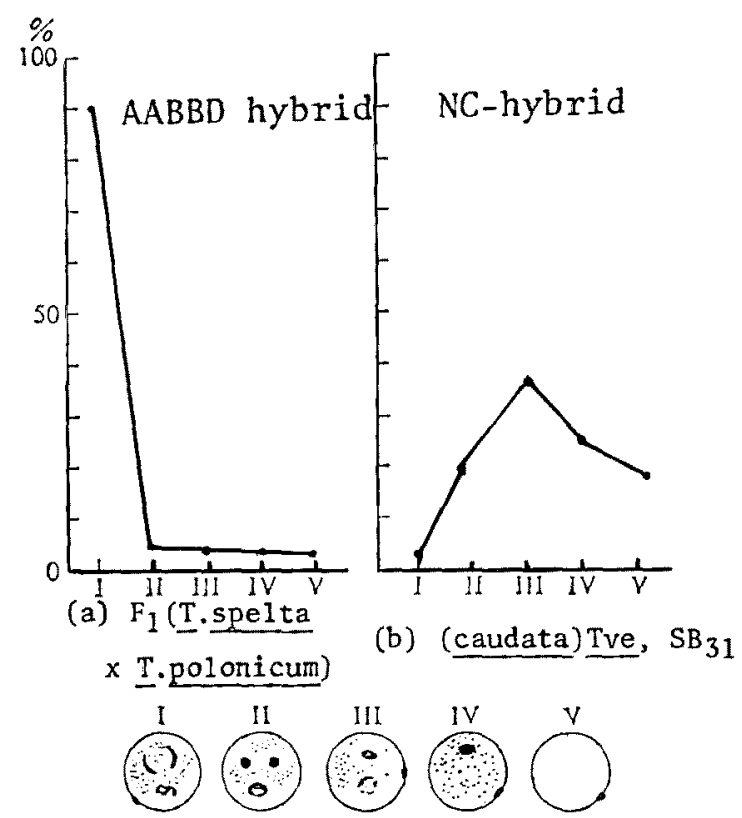

Fig. 3. The proportions of five pollen types in interspecific hybrid and nucleo-cytoplasmic hybrid. hybrid like (caudata)Tve is as shown in Fig. 3b. Sterility of triploid hybrids reported in Avena (Nishiyama 1934) and Allium (Levan 1936) is also included in the first category. On the other hand, the sterility of a triploid wheat hybrid obtained from the cross of Emmer and Einkorn is composed of the combination of two categories, because their cytoplasms are identified to be different each other. This is the reason the triploid wheat hybrid is highly sterile, while the triploid Avena has some fertility even though they have the same meiotic configuration of $7_{\mathrm{II}}+14_{1}$.

I have once given a lecture about why the male sterility occurs in alloplasmic individuals. My tentative theory was as follows; somatic cells don't divide simultaneously, while the microspores divide simultaneously requiring enormous physiolosical activities. In this case, the requirement of DNA for all microspores must be abundant. The shortage of DNA might be the cause of pollen sterility. This idea is quite in accord with the normal frequency distribution curve of pollen grains from type I to type V (Fig. 3a). On the contrary, sterility caused by genomic defficiency (loss of chromosomes) makes almost all pollen grains have no content of starch, causing skew distribution of pollen types (I-V) (Fig. 3b).

The tentative classification of pollen sterility might not be applied to the sterility due to zygotic lethality like (squarrosa)AABB.

V. Significance of amphidiploid for the study of evolution

The first report on the synthesis of an amphidiploid species was accomplished in 
Galeopsis by Müntzing as early as in 1930. The method was rather complicated as colchicine method was not known yet. It was easy to obtain amphidiploids by colchicine treatment of $\mathrm{F}_{1}$ hybrids. One of such examples is synthesized Aegilops triuncialis $\left(\mathrm{CCC}^{u} \mathrm{C}^{u}\right)$, obtained from the cross of Ae. caudata $(q)$ and Ae. umbellulata $(\delta)$. We have two strains of the amphiploids; one is produced by Sears (1939) and the other by Kondo (1941).

These two strains were unstable in relation to their chromosome pairing as well as fertility. However, after repeated selfing, these two strains became stable in chromosome pairing and fertility (Fig. 4). We assume that the stability of amphidiploids might be established through mutual adjustment between foreign genome and plasmon within the amphidiploid cells. Aegilotricum $(8 \mathrm{x})$ obtained by Tschermak in 1925 is in our collection. This strain is still unstable giving rise some aneuploid offsprings. Our synthesized common wheats (ABD strains) strains are also somewhat unstable after 35 years.

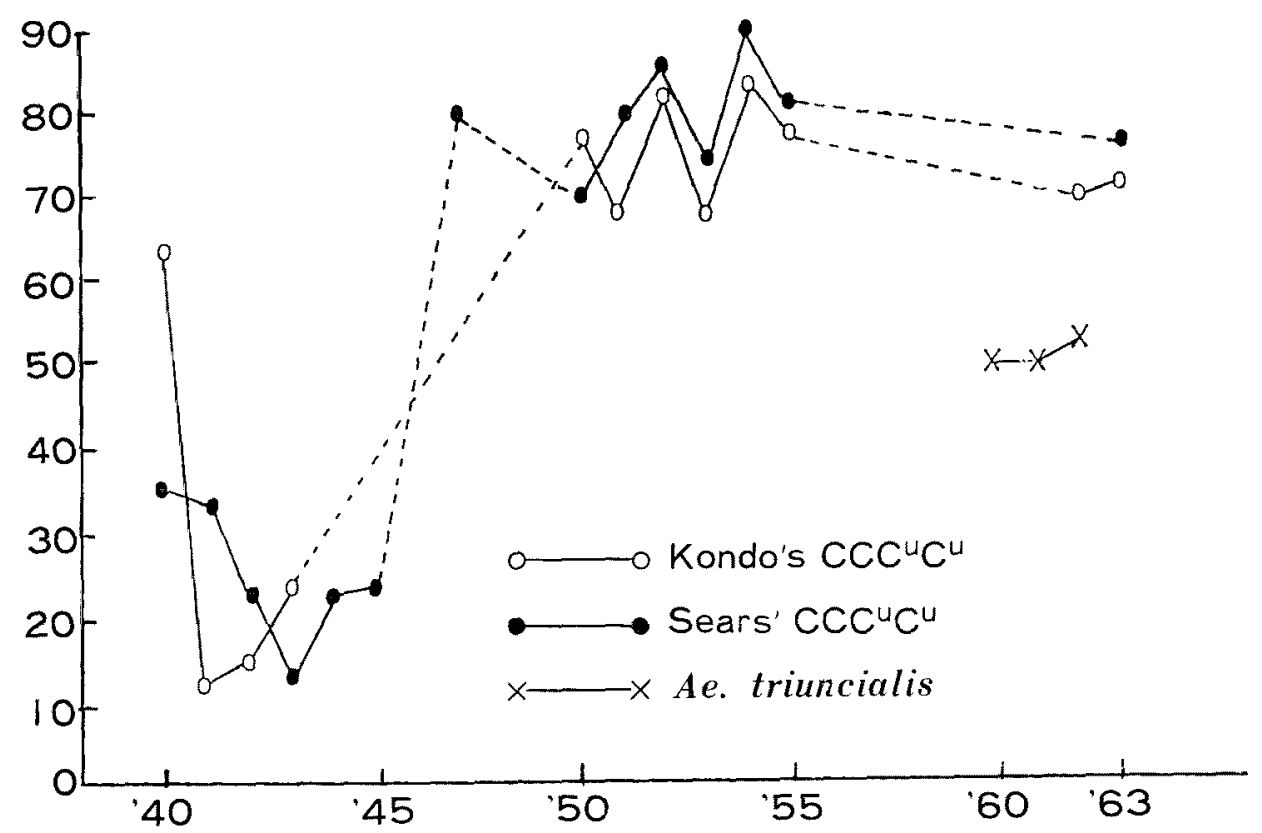

Fig. 4. Seed fertility of two stsains of sythesized Aegilops triuncialis, $\mathrm{CCC}^{u} \mathrm{C}^{\mathrm{u}}$ (Kihara 1965).

The natural amphidiploid Ae. triuncialis is widely spread along the Mediterranean coast and islands (Fig. 5). Most of polyploid species in Aegilops have wider distribution than the diploids. This seems to mean that they are more adapted to different environments than the diploids. It was proved by Love and Love (1975) that polyploids are found much more than the diploids in the Arctic zone (Table 8).

Now, let us try to estimate the place of the creation of Ae.triuncialis. From the distribution of the parental species of Ae. caudata and umbellulata, the amphidiploid might be originated around the coast of the Black Sea. Eig (1929) suggested that Aegilops (4x species) might have completed their spreading between the Diluvium 
and the Miocene, as the area around the present Mediterranean Sea was totally under water during the Oligocene, an epoch just before the Miocene. Thus the time of creation of the amphidiploid could be presumed to be during the Miocene. This'

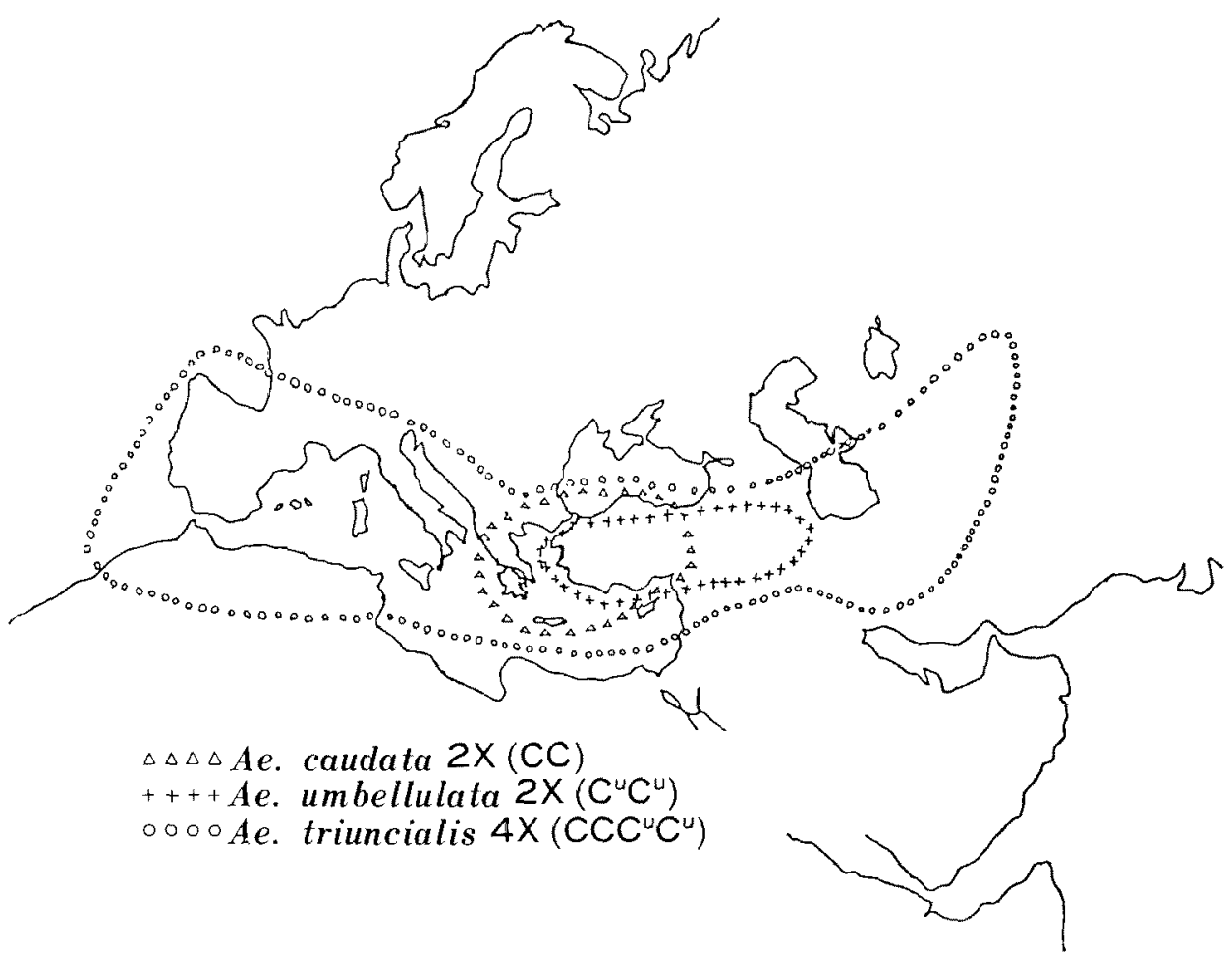

Fig. 5. Distribution of Ae, triuncialis L. and its parental analysers (Eig 1929).

Table 8. Frequency of polyploids in the Arctic zones

\begin{tabular}{ccc}
\hline Arctic Zones & Diploids & Polyploids \\
\hline Lowarctic & $40 \%$ & $60 \%$ \\
Higharctic & $20 \%$ & $80 \%$ \\
\hline
\end{tabular}

(Love and Love 1975)

Table 9. Three examples of species hybrids whose parents are separated for long time

\begin{tabular}{lccll}
\hline Hybrid & $\begin{array}{c}\text { Chromosome } \\
\text { pairing }\end{array}$ & Fertility & \\
\hline Platanus orientalis & $\times$ Platanus acerifolins & $21_{\mathrm{II}}$ & normal & Sax, 1933 \\
Campsis sinensis & $\times$ Campsis radicans & $21_{\mathrm{II}}$ & $50 \%$ & Sax, 1933 \\
Fragaria elatior & $\times$ Fragaria nipponica & $14_{\mathrm{Ir}}$ & almost & Lilienfeld, 1933 \\
& & & & normal
\end{tabular}

assumption corresponds to the existence of Ae. triuncialis on the islands like Sicily, which was a part of the connecting bridge between Europe and Africa. The age of the geological epoch can not be calculated accurately. Still we can assume that the amphidiploid species was created multimillion years ago. 
As the genomes of Ae. triuncialis are almost identical with those of Ae. caudata and $A e$. umbellulata, we can say that the genome and plasmon remain relatively constant for long time. I can show two examples of plants whose genomes and plasmon retain their constancy after multimillion years of separation in Table 9.

\section{Role of cytoplasm in evolution of plants}

Genetic studies have been mainly concentrated to the studies on nuclear genomes, whereas the cytoplasmic hereditary materials like plasmon (a counterpart of nuclear genome) have not been sufficiently explored. However, we have to reconsider that the cytoplasm is very important site for genetical and physiological activities in response to the nuclear genes. We can compare the relationship between nucleus and cytoplasm as the former a blueprint and the latter a factory.

So far, the intimate relationships between these two components which I am aware of, are summarized as follows:

1) Correspondence of one gene and one cytoplasmic unit found in the fertility restoration of male sterile cytoplasm.

2) One gene, one enzyme theory (cited from Beadle 1966), and similar examples.

3) Photosynthesis activities within plastids and respiration activities within mitocondoria, controled by their plasmons and nuclear genes (Imai 1937).

4) Gene-for-gene phenomena between host plant and pathogen for disease resistance and susceptibility; although this seems to be different from the other categories, it is one of good examples for correspondence of genome with extranuclear factor. This phenomenon was found firstly in flax by Flor (1954) and in other cultivated plants, later.

The whole cytoplasmic units are transmitted to the offspring from maternal parent, and no paternal cytoplasm is given to the next generation, while nuclear components are composed of parental chromosomes half-by-half. This means in heredity that substances from maternal side are much more than those from the paternal side. Moreover, two thirds of genetic materials of endosperm are given from the maternal parent in plants, which influences plant growth during young stage very much. In short, the living organisms, especially in higher plants, get larger contributions from their mothers.

Although the evolution of living organisms has been discussed mostly from the standpoint of nuclear genes, the genetic substances in cytoplasm must have played important or sometime crucial roles in evolution. Genetic changes of nuclear genes might be selected by the hereditary components of cytoplasm.

Although the inheritance of acquired characters has not been proved so far, we have to reconsider it because it has been proved that infective microorganisms could stay in the cytoplasm of the host to become hereditary units and to control the genetic manifestation of nuclear genes. The cytoplasmic consititution is especially important for evolution through species hybridization.

Grun (1976) reviewed the cytoplasmic inheritance in plants and proposed his ideas of cytoplasmic roles in evolution which referred to the coadaptation between cytoplasmic particles and host, and cytoplasmic factors as isolating barriers. 
Table 10. Classification of Triticum and Aegilops by means of genome analysis and possible origin of cytoplasms in allopolyploid species estimated from NC-hybrids

Species name Genome* $\quad \begin{gathered}\text { Origin of } \\ \text { cytoplasm }\end{gathered}$

\section{Triticum}

Einkorn

boeoticum

monococcum

Emmer wheat

dicoccoides

turgidum

Timopheevi wheat

araraticum

timopheevi

zhukovskyi

Common wheat

aestivum (vulgare)

Aegilops

Polyeides

umbellulata

ovata

triaristata $(4 x)$

columnaris

biuncialis

variabilis

kotschyi

triuncialis

triaristata $(6 x)$

Cylindropyrum

caudata

cylindrica

Comopyrum

comosa

heldreichii

uniaristata

Amblyopyrum

mutica

Sitopsis

speltoides

longissima

sharonensis

bicornis

Vertebrata

squarrosa

crassa $(4 x)$

ventricosa

crassa $(6 x)$

juvenalis

vavilovii
AA

AA

$\mathrm{AABB}$

$\mathrm{AABB}$

AAGG

AAGG

AAGGGG

AABBDD

$\mathrm{C}^{u} \mathrm{C}^{\mathrm{u}}$

$\mathrm{C}^{\mathrm{u}} \mathrm{C}^{\mathrm{u}} \mathrm{M}^{\mathrm{o}} \mathrm{M}^{\mathrm{o}}$

$\mathrm{C}^{\mathrm{u}} \mathrm{C}^{\mathrm{u}} \mathrm{M}^{\mathrm{t}} \mathrm{M}^{\mathrm{t}}$

$\mathrm{C}^{\mathrm{u}} \mathrm{C}^{\mathrm{u}} \mathrm{M}^{\mathrm{e}} \mathrm{M}^{\mathrm{c}}$

$\mathrm{C}^{\mathrm{u}} \mathrm{C}^{\mathrm{u}} \mathbf{M}^{\mathrm{b}} \mathrm{M}^{\mathrm{b}}$

$\mathrm{C}^{\mathrm{a}} \mathrm{C}^{\mathrm{u}} \mathrm{S}^{\mathrm{v}} \mathrm{S}^{\mathrm{v}}$

$\mathrm{C}^{\mathrm{u}} \mathrm{C}^{\mathrm{u}} \mathrm{S}^{\mathrm{v}} \mathrm{S}^{\mathrm{v}}$

$\mathrm{C}^{\mathrm{u}} \mathrm{C}^{\mathrm{u}} \mathrm{CC}$

$\mathrm{C}^{\mathrm{u}} \mathrm{C}^{\mathrm{u}} \mathrm{M}^{\circ} \mathrm{M}^{\circ} \mathbf{M}^{\mathrm{t}} \mathbf{M}^{\mathrm{t}}$

$\mathrm{CC}$

CCDD

MM

MM

$\mathrm{M}^{\mathrm{u}} \mathrm{M}^{\mathrm{u}}$

MtMt

SS

$S^{1} S^{1}$

$S^{1} S^{1}$

$\mathrm{S}^{\mathrm{b}} \mathrm{S}^{\mathrm{b}}$

DD

$\mathrm{DDM}^{\mathrm{cr}} \mathrm{M}^{\mathrm{cr}}$

$\mathrm{DDM}^{\mathrm{v}} \mathrm{M}^{\mathrm{v}}$

$\mathrm{DDD}^{2} \mathrm{D}^{2} \mathrm{M}^{\mathrm{er}} \mathrm{M}^{\mathrm{er}}$

$\mathrm{DDM}^{\mathrm{j}} \mathrm{M}^{3} \mathrm{C}^{\mathrm{u}} \mathrm{C}^{\mathrm{u}}$

$\mathrm{DDM}^{\mathrm{cr}} \mathbf{M}^{\mathrm{er}} \mathrm{S}^{\mathrm{p}} \mathrm{S}^{\mathrm{p}}$
A

A

B

B

G

G

G

B

$\mathrm{C}^{\mathrm{n}}$

$\mathrm{M}^{\circ}$

$\mathrm{C}^{\mathrm{u}}$

$\mathrm{C}^{\mathrm{u}}$

$\mathrm{C}^{u}$

$S^{v}$

$S^{v}$

$\mathrm{C}^{\mathrm{u}}$ or $\mathrm{C}$

$\mathrm{C}^{\mathrm{u}}$

C

D

M

$\mathrm{M}$

$\mathrm{M}^{\mathrm{u}}$

Mt

$\mathrm{S}$

$S^{1}$

$S^{1}$

$S^{\mathrm{b}}$

D

D

D

D

D

D

* After Kihara and Tanaka (1970). Instead of $\mathrm{C}^{a}$ a new symbol, $U$ is proposed for the genome of Ae. umbellulata.

** After Kihara $(1975,1979)$ and Tsunewaki (1980). 
In wheat and its relatives, it was proved by the nucleo-cytoplasmic substitution analysis that all diploid species having different genome constitution had genetically different cytoplasm each other (Kihara 1973, 1975, Maan 1976, Tsunewaki 1980). This fact indicates that differentiation of nuclear genomes is corresponded by the differentiation of cytoplasms. It is, also, proved that their polyploid species which have evolved through interspecific hybridization and amphidiploidization are cytoplasmically identical or similar to the one of their parental genome donors as summerized in Table 10.

It is interesting to note in this table that a group of species classified by genome analysis has a tendency to have genetically a common cytoplasm. For example, whole species belonging to the section Vertebrata are cytoplasmically identical or similar to that of Ae. squarrosa in spite of ploidy difference. This means that $A e$. squarrosa had contributed not only its nuclear genome, but also its cytoplasmic components to these species in evolution. These facts indicate that the cytoplasmic components might have played an important role in the evolution of species by hybridization.

As mentioned earlier, many experiments showed that pollen fertility of plant species is controlled by the interaction between fertility restoration genes in nucleus and cytoplasmic factors. Studies of nucleo-cytoplasmic substitution lines in wheat indicated that cytoplasm influenced almost all plant characters in various degrees, including lethality. Dominance-recessiveness of allelic genes or, also, genetic lethality might be the results of disharmony between corresponding nuclear and cytoplasmic units. Imai (1937) proposed the term 'plastogene' for genes which were transmitted through plastids and suggested that a nuclear gene controlled the mutability of cytoplasm. Michaelis $(1935,1949)$ also proposed the concept of plasmasensitive gene which interacted with the corresponding cytoplasm in his studies on Epilobium. There must be a close relationship between cytoplasm and nucleus, in which even a small change (mutation) in the nucleus has to be compatible with cytoplasm for adaptation. The reverse even might be, also, possible.

In conclusion, the evolution of plant spcecies must be the result of coordination of two hereditary units, genome and plasmon.

\section{References}

Beadle, G. 1966. The Language of Life. Doubleday Co. New tork. pp. 242.

Eig, A. 1929. Morphologisch-kritische Übersicht der Gattung Aegilops. Rep. sp. nov. reg. 65.

Flor, H. H. 1956. The complementary genic systems in flax and flax rust. Adv. Genetics 8: 29-53. Grun, P. 1976. Cytoplasmic Genetics and Evolution. Columbia Univ. Press. New York. pp. 435. Hirai, A., Uchimiya, H. and Sugiura, M. 1981. Chloroplast gene expression in calli derived from hetrofusion cells. Jap. J. Genet. 56: 599.

Imai, Y. 1937. Chlorophyll variegations due to mutable genes and plastids. Z. indukt. Abstamm.u. Vererb. Lehre $71: 61-83$.

Kasha, K. J. 1974. Haploids from somatic cells. Proc. 1st Intern. Symp. Univ. of Guelph. Guelph : 67-87.

Kihara, H. 1951. Substitution of nucleus and its effects on genome manifestation. Cytologia 16: $177-193$.

- 1959. Fertility and morphological variation in substitution and restitution backcrosses of 
hybrids, Triticum vulgare $\times$ Aegilops caudata. Proc. Xth Intern. Congr. Genet.

- 1965. The origin of wheat in the light of comparative genetics. Jap. J. Genet, 40: 45-54.

- 1973. Characteristics of Aegilops squarrosa cytoplasm. Proc. IVth Intern. Wheat Genet. Symp. Missouri.

- 1975. Plant genetics in relation to plant breeding research. Seiken Ziho 25/26: 25-40.

- 1979. Nucleo-cytoplasmic hybrids and nucleo-cytoplasmic heterosis. Seiken Ziho 27/28: 1-13.

- and Y. Ohta. 1971. Interspecific genome differentiation in Aegilops caudata. Seiken Ziho 22: 99-106.

- and Tanaka, M. 1958. Morphological and physiological variation among Aegilops squarrosa strains collected in Pakistan, Afghanistan and Iran. Preslia 30.

- and - 1970. Addendum to the classification of genus Aegilops by means of genome-analysis. Wheat Inf. Serv. $30: 1-2$.

- and Kishimoto, E. 1942. Embryological studies on the formation of haploid embryo in Triticum monococcum. Seiken Ziho 1 : 3-9.

Kinoshita, T., Ohtsuka, I. and Kihara, H. 1980. Alteration of growth habit and variation of heading time induced by the alien cytoplasm in common wheat. Wheat Inf. Serv. 50: 65-70.

Kondo, N. 1941. Chromosome doubling in Secale, Haynaldia and Aegilops. Jap. J. Genet. 17: $46-53$.

Lilienfeld, Flora 1933. Karyologische und genetische Studien an Fragaria I. Jap. J. Bot. 6: 24-29.

Love, A. and Love, D. 1975. Cytotaxonomical Atlas of the Arctic Flora. Kramer (Germany).

Maan, S. S. 1976. Cytoplasmic Variability and Speciation in Triticinae. Prairie, Univ, of North Dakota Press: 255-281.

Melchers, G., Sacristan, M. D. and Holder, A. A. 1978. Somatic hybrid plants of potato and tomato regenerated from fused protoplasts. Carlsberg Res. Commun. 43: 203-218.

Michaelis, P. 1935. Entwicklungsgeschichtlichgenetische Untersuchungen an Epilobium III. Zur Frage der Übertragung von Pollenschlauchplasma in die Eizelle und ihre Bedeutung für die Plasmavererbung. Planta 23: 486-500.

- 1949. Über Abanderung des plasmatischen Erbgutes. Z, indukt. Abstamm.-u. VerebLehre 83: 36-85.

Mukade, K., Kamio, M. and Hosokawa, K. 1973. The acceleration of generation advancement in breeding rust-resistant wheat. Proc. IVth Intern. Wheat Genet. Symp., Missouri.

Müntzing, A. 1930. Über Chromosomen-Vermehrung in Galeopsis-Kreuzungen und ihre phylogenetische Bedeutung. Hereditas 14: 23-34.

Nishiyama, I. 1934. The genetics and cytology of certain cereals VI. Chromosome behavior and its bearing on inheritance in triploid Avena hybrids. Mem. Coll. Agr. Kyoto Imp Univ. 32: $1-157$.

Sax, K. 1933. Species hybrids Platanus and Campsis. J. Arnold Arb. 14: 20-28.

Sears, E. R. 1939. Amphidiploids in Triticinae induced by colchicine. J. Hered. 30: 16-22.

Tsunewaki, K. 1980. Genetic diversity of cytoplasm in Triticum and Aegilops. Jap. Soc. Prom. Sci. Tokyo. pp. 300.

Yuasa, A. 1980. Genesis of human-mouse hybrid (In Japanese). Jiyu-kokumin-sha (Tokyo). 